\title{
Attitudes Towards Exogenous and Endogenous Uses of English: Ugandan's Judgements of English Structures in Varieties of English
}

\author{
Christiane Meierkord ${ }^{1}$ \\ ${ }^{1}$ Department of English, Ruhr-University of Bochum, Bochum, Germany \\ Correspondence: Christiane Meierkord, Department of English, Ruhr-University of Bochum, Universitatsstr. 150, \\ 44801 Bochum, Germany. E-mail: christiane.meierkord@rub.de
}

Received: September 28, 2019 Accepted: October 20, 2019 Online Published: December 10, 2019

doi:10.5539/ijel.v10n1p1 URL: https://doi.org/10.5539/ijel.v10n1p1

\begin{abstract}
Uganda is a former British protectorate, where English has contributed to the country's linguistic ecology since 1894, when the British established a protectorate over the area of the Buganda kingdom. Over time, Ugandan English has developed as a nativised second language variety, spoken by Uganda's indigenous population. At the same time, due to migrations, globalisation and the influence of international media and the Internet, its speakers have increasingly been in contact with varieties other than British English: American English, Indian English, Kenyan English, and Nigerian English may all influence Ugandan English. This paper looks at how Ugandan English can be conceptualised as a variety shaped by other varieties. It reports on the results of acceptability tests carried out with 184 informants in the North, the Central and the West of Uganda and discusses how speakers assess individual grammatical structures used in Ugandan English and in those varieties they are potentially in contact with.
\end{abstract}

Keywords: Uganda, varieties of English, acceptability tests, models of world Englishes

\section{Introduction}

Uganda is a country in East Africa, adjacent to South Sudan in the North, Kenya in the East, the Democratic Republic of Congo to the West and Rwanda and Tanzania in the South. From 1875, the English language has been making inroads in the country's linguistic ecology, starting with a few explorers, then missionaries, and eventually, when the British extended a protectorate over what today is Uganda in 1900, administrative personnel, traders etc. (cf. Meierkord, 2016a). As in most countries that, as a result of similar histories, have English as a second language (L2), a nativised variety of English, Ugandan English (UgE, cf. Meierkord et al., 2016) has developed over time. While it has been influenced, on the one had, by its speakers' 39 indigenous languages, it has, historically, been shaped by British English (BrE) and, more recently, increasingly by those Englishes that reach the country via the Internet and migrations.

This paper presents a first step towards assessing how these Englishes influence Ugandan speakers of English, through discussing the results of 184 acceptability tests that probe into how speakers in different parts of the country judge individual English structures that express futurity, obligation, ability and spatial as well as temporal relations. For these five areas, differences exist as regards the way they are expressed in three of the major first languages (L1): Acholi, Luganda, and Runyankore, spoken in the North, the Central and the Western parts of the country.

\section{Research on Ugandan English}

As is the case with many other former British and US American protectorates, Uganda has, until recently, not received a lot of attention from within English linguistics (Note 1). Up until the 2000s, scholarly research on $\mathrm{UgE}$ was restricted to passages in the somewhat outdated Lagefoged et al. (1972). Since 2000, a few isolated individual book chapters (i.e., Ssempuuma, 2013; Nelson \& Hongtao, 2012) and journal articles (Fisher, 2000; Isingoma, 2013, 2014a; Nassenstein, 2016) have been published, but these cater for limited aspects of UgE only and are sometimes sketchy and not based on empirical evidence. Given these limitations, Uganda and UgE are also largely missing from most compendiums and handbooks of World Englishes (e.g., McArthur, 2002; Kortmann \& Schneider, 2004; Kirkpatrick, 2007; Schneider, 2007, 2011; Filppula et al., 2017, although it is briefly mentioned in the latter two). Merely Kortmann and Lunkenheimer (2013) include a dedicated chapter that 
covers UgE. At the same time, a number of dissertations describe both the structure and usage of English in Uganda (e.g., Mugumya, 2013; Nakayiza, 2013; Ssentanda, 2014a; Tukwasibwe, 2014; Bayiga, 2016), and several of the authors subsequently disseminated their research results in internationally accessible journals (e.g., Isingoma, 2013, 2014a\&b, 2016a; Namyalo \& Nakayiza, 2014; Ssentanda, 2014b; Ssentanda et al., 2016).

In 2016, a dedicated volume (Meierkord, Isingoma, \& Namyalo, 2016) provided a first detailed description of the sociolinguistic situation and individual features of UgE. More recent research includes Ssempuuma (2019) and Isingoma and Meierkord (2019), both continuing to describe the variety, with the aim of understanding how it is (dis)similar to other varieties of English spoken in East Africa and how this can be reflected in models of world Englishes.

The publications on UgE reveal characteristics that set it apart from other East African Englishes. Besides lexical borrowings, which are largely from Luganda rather than from Kiswahili, progressives are used significantly less often in UgE than in data from Kenya and Tanzania (Ssempuuma et al., 2016), and analyses of diphthongs reveal significant differences across L1 backgrounds (Meierkord, 2016b). This is in contrast to earlier discussions of UgE under the label 'East African English' (cf. Schmied, 2004a, 2004b; Wolf, 2010; but see Schmied 2006 and 2017 for more diversified accounts acknowledging lexical and morphosyntactic differences), which were based on the assumption that the Englishes of the area share an influence of Kiswahili. Research has revealed that this influence is very limited in Uganda (Rosendal 2010). Despite its status as a co-official language and the resulting institutional support (particularly as regards Kiswahili as a school subject), Kiswahili seems to play a negligible role in the media, print publications, religion and informal private interactions (Namyalo et al., 2016) and to only have some currency in the Northern province. In fact, Fisher $(2000,58 \mathrm{f}$.) had already concluded that "although genetically similar, in the same way that Australian and New Zealand English share a common ancestor, UE $[\mathrm{UgE}, \mathrm{cm}]$ has diverged from the other East African varieties", claiming that it is mainly influenced by Luganda, the L1 of $17.98 \%$ of Uganda's population and a widely used L2 in the country.

Whilst Ugandan English thus is interesting as a distinct variety in itself and in comparison to other East African Englishes at a descriptive level, it is also, and maybe particularly, of theoretical interest, as it lends itself to further refining current models of world Englishes.

\section{Ugandan English in Recent Modelling of World Englishes}

Models of world Englishes are numerous and have been proposed for over half a century now. Whilst some of these focus on how speakers' L1s influence their variety of English and how this leads to nativisation and potentially to acceptance of local forms, others assume that varieties of English are influenced by other varieties. Moving on from the somewhat static earlier models offered by Quirk et al. (1985) and Kachru (1985), which classified speakers as using English either as their native (ENL), as a second (ESL) or as a foreign (EFL) language and assigned countries to an Inner, Outer and Expanding Circle, respectively, recent models aim at accounting for the dynamic character of varieties of English, and for their interaction with and impact on each other. As Schneider (2011, p. 32) argues, the two older models "fail to reflect the vigorous spread of English and changes of its status in many regions over the last few decades" and do not fully reflect the complex realities of many areas (Note 2). In fact, countries assigned to the Outer Circle frequently exhibit characteristics of the Expanding Circle, as the use of individual features as well as the sociolinguistic realities cut across the ESL-EFL divide (see e.g. Biewer, 2011, p. 11; Michieka, 2009). In Uganda's capital Kampala, English pervades the lives of people, and individual families have been found to raise their children in English, whilst the rural area of Karamoja is more representative of the Expanding Circle, given the very limited use of English there.

Models which currently seem apt to describe the realities of $\mathrm{UgE}$, but which would benefit from further refinements and/or cross-fertilisation to better cater for post-protectorate Englishes seem to be Schneider's (2007) Dynamic Model, Mair's (2013) World System of Standard and Non-standard Englishes, and Meierkord's (2012) Interactions across Englishes, in conjunction with Mufwene's (2001) feature pool model.

Schneider's (2007) highly influential Dynamic Model assumes that postcolonial Englishes follow a uniform trajectorial development, comprising the five stages of "(1) foundation, (2) exonormative stabilisation, (3) nativization, (4) endonormative stabilization, and (5) differentiation" (2007, p. 30). As shown in Ssempuuma, Isingoma and Meierkord (2016), Isingoma (2016a \& b), Meierkord (2016b) and Meierkord (2016c), UgE is in its nativisation phase, linguistically characterised by heavy borrowing, phonological variability and structural nativisation (cf. Schneider, 2007, pp. 44-47).

Mair's (2013) World System of Standard and Non-Standard Englishes further allows to integrate aspects of globalisation (cf. Blommaert, 2010) and the, assumed, spread and influence of other varieties on UgE. Mair (2013, p. 256) argues that "at least in principle, all Englishes are everywhere" and assigns varieties to four 
hierarchical categories, depending on their transnational impact in terms of their demographic weight and institutional support (through their use as official language, codification and/or their presence in the media). Crucially, the model makes the novel assumption that a number of non-standard varieties of English have a higher influence on others than some of the standard varieties. In particular, Mair discusses Jamaican Creole as spreading through its presence in popular music, which has resulted in borrowings from this variety (e.g., words such as "yard for 'home', bashment for 'party' and the pronunciation [a:ks] for ask") by London teenagers (Mair, 2013, p. 265). In Uganda, it is particularly Indian English (IndE), Nigerian English (NigE), Kenyan English (KenE) which may exert an influence on UgE (Note 3). Exposure to KenE, spoken in the neighbouring country, is via trade and other businesses. IndE has been endogenous in the country ever since the return of parts of the Asian community and the arrival of new Asian immigrants and is reflected for example in the word chapati that is regularly used in UgE (see Isingoma \& Meierkord, 2019). Further, IndE (Note 4) and NigE have spread to Uganda via Bollywood and Nollywood films and TV series, which are popular in the country.

Both Schneider (2007) and Mair (2013), however, treat UgE as a homogenous single entity. Yet, since L2 speakers of English in Uganda have Bantu (66.4 \%) Nilotic (27.2 \%), Central Sudanic (6.3\%) and Kuliak (0.1\%) L1s, the country seems to be home to several Englishes, albeit sharing a 'national' core (cf. Isingoma, 2013, 2014a, 2016b). Meierkord (2012) caters for this and for exogenous influence in that her Interactions across Englishes (IaEs) model assumes that speakers of English as an L2 potentially bring their very own varieties of English into an interaction conducted with speakers who have different L1 backgrounds. Not dissimilar to what happens in dialect contact, the features of these various varieties enter into a feature pool (Mufwene, 2001), where they are available for selection by the other speakers and for recombination into new linguistic systems. Generally, IaEs take place in very diverse contexts and may be between a Chinese and a Mexican participant at a scientific conference, or between a Sri Lanka-born chef and a Ukrainian room maid at a hotel in Cornwall. For the East African context, Schmied (1991, p. 420) observes this for Kenya and finds that, e.g., "a Luo hotel manager may talk in basilectal English to his Kikuyu cleaners and in acrolectal English to his foreign guests". S/he may choose a variety of English to "suggest a distinct identity [or social disposition] to the hearer". In Uganda, IaEs are highly likely to take place, given the multilingual nature of the country. They may, for example, involve speakers whose L1s are Acholi, Luganda and Runyakitara (see Namyalo et al., 2016 on details for Uganda's languages). Since these interactions typically occur in very diverse constellations of speakers, a heterogeneous array of linguistic systems is the result, rather than one stable variety. Only prolonged contact, potentially, results in new emergent varieties (Note 5).

One factor that constrains whether speakers use a particular feature or not is whether they deem it acceptable. In fact, Hundt (2013) submits that verifying influence of one variety on another must take a mixed-methods approach, including attitudinal data. Acceptability tests are generally held to provide insights into informants' prescriptive attitude towards individual grammatical structures or lexical items (e.g., Loewen \& Reinders, 2011).

We focus on attitudes towards expressions of futurity, obligation, ability and spatial a well as temporal relations, which are indicated through different surface structures in Acholi, Luganda and Runyankole, and which speakers of these L1s potentially realise differently in their L2 Englishes. Moreover, these features have also been found to differ across world Englishes (cf. the synopses in Kortmann \& Schneider, 2004 and the overviews in Kortmann \& Lunkenheimer, 2013), so that we have also been able to test, albeit to varying degrees, whether structures typical for the exogenous varieties of English mentioned above are acceptable to Ugandan speakers of English.

The expressions included in the acceptability tests cover what Mair (2013) has labelled the hyper-central, or 'hub', form American English (AmE), said to exert influence on all other varieties, several super-central and central varieties as well as the endogenous variety (UgE) itself to uncover what the results of our attitudes studies reveal about Ugandans' normative preferences and what we may deduce from their judgments regarding the modeling of English. Whilst AmE is today encountered via media, particularly music, films and the Internet, $\mathrm{BrE}$ has been the target of English language teaching ever since the country's history of English presence.

\section{Data and Methodology (Note 6)}

The acceptability tests were conducted with a total of 184 speakers of diverse L1s, with one third of these being year six secondary students (aged 18 or 19), another third being university students and a final third being professionals ranging from hair dressers and seamstresses to mobile money agents and sales representatives. All participants had received English instruction until the end of secondary school. Data were collected in Gulu, Kampala and Mbarara. The choice of these three locations was motivated by the differences in the likelihood of an influence of the English of Luganda L1 speakers on the Englishes of speakers with other L1s. Whilst the 
schools and universities in Kampala and Mbarara have, due to their prestige, sizeable intakes of pupils with Nilotic L1s as well as Luganda, Luganda-speaking students hardly ever enrol in schools or universities in the Gulu area, since prestigious institutions exist closer to their homes. Hence, direct influence from regular interaction with Luganda L1 speakers can be ruled out to some extent here, and if speakers still displayed Luganda influence, then this would indicate nation-wide influence from Luganda through e.g., the presence of Luganda speakers of English in the media (which results from the fact that many Baganda hold official positions) and the fact that Luganda is learnt as a second language by many Ugandans.

Each of the participants rated 52 sentences on a 4-point Likert scale from "fully acceptable" (1), via "somewhat acceptable"(2) and "somewhat unacceptable" (3) to "completely unacceptable" (4). In addition, they were given the option of ticking a box stating "I do not understand the sentence", to avoid their ticking a box without being able to rate the sentence at all.

\section{Ugandans' assessment of grammatical structures in various Englishes}

Based on the assumption that Ugandans' assessments of a structure's acceptability is constrained by a) the structures that are available in their L1s, which they potentially transfer into their L2 English and thus find acceptable, and by b) regularly encountering the structure in the English of other speakers, both of UgE and of various other varieties of English, futurity, modals of obligation and ability, and spatial as well as temporal prepositions were chosen as features of analyses.

\subsection{Assessments of Expressions of Futurity}

As is well known, English does not have a future tense but employs various strategies to express future time: "future time is typically marked in the verb phrase by modal or semi-modal verbs such as will, shall, be going to" (Biber et al., 1999, p. 456), but also through the use of the simple present or the present progressive.

In the Bantu languages, futurity takes two tenses: Luganda has a general and a near future, whilst Runyankore has a near and a far future. In Runyankore, the 'near future' is formed with the progressive form of the verb -ija ('come'), preceding the infinitive of the main verb, whilst the 'far future' is formed by the infix -rya- (Taylor, 1985, p. 153). Somewhat different, in Luganda both 'near future' and 'general future' are formed through infixes, -naa- and -li- respectively (Ashton, 1954, p. 124). The degree to which these distinctions transfer into the speakers' L2 Englishes is unclear (Note 7). For UgE, however, Ssempuuma (2013) rates the use of different modals for distant future, i.e., would for (distant) future in contrast to will as extremely rare. In Acholi, there is only one future tense, which is only formed in the indicative and expressed through the marker - $b i$ - (cf. Kitching, 1932, p. 15). Furthermore, the etymology of individual future constructions (all are grammaticalised verbs originally meaning 'come') found in all three languages seems to be reflected in the 'come-based future/ingressive marker', which Huber (2013) identifies as one of four features that are "considerably more widespread in African Englishes as a whole as opposed to the rest of the world's Englishes" (2013, p. 823). In fact, the form is typically absent in British English varieties and in KenE and Tanzanian English but widespread in West African Englishes. Ssempuuma (2013) holds it to be somewhat frequent in UgE.

The twelve test items presented to the informants included sentences that contained a standard English (BrE or AmE, following Biber et al., 2000) construction that expresses future time (those items that have no comments in the lists below) as well as forms that have been attested in Trudgill and Hannah (2017), Mesthrie and Bhatt (2008) or McArthur (2002) for IndE, mentioned above as a potential contact variety.

2_FUT1: I wish that can happen soon.

4_FUT2: We are going there next Tuesday.

7_FUT3: We are to discuss this next week.

11_FUT4: It is coming to rain. (UgE)

18_FUT5: We will be meeting next week.

21_FUT6: I would visit my parents tomorrow.

30_FUT7: She is coming here next week.

35_FUT8: I buy a new dress for the wedding.

39_FUT9: We shall need the money on the 15th.

45_FUT10: When you will arrive, please visit me. (IndE)

48_FUT11: The city would be building a new hospital in 2025. (IndE) 
52_FUT12: I am going to travel to Kampala next week.

As Figure 1 displays, the informants in Gulu, Kampala and Mbarara rated the various test items drastically different from each other.

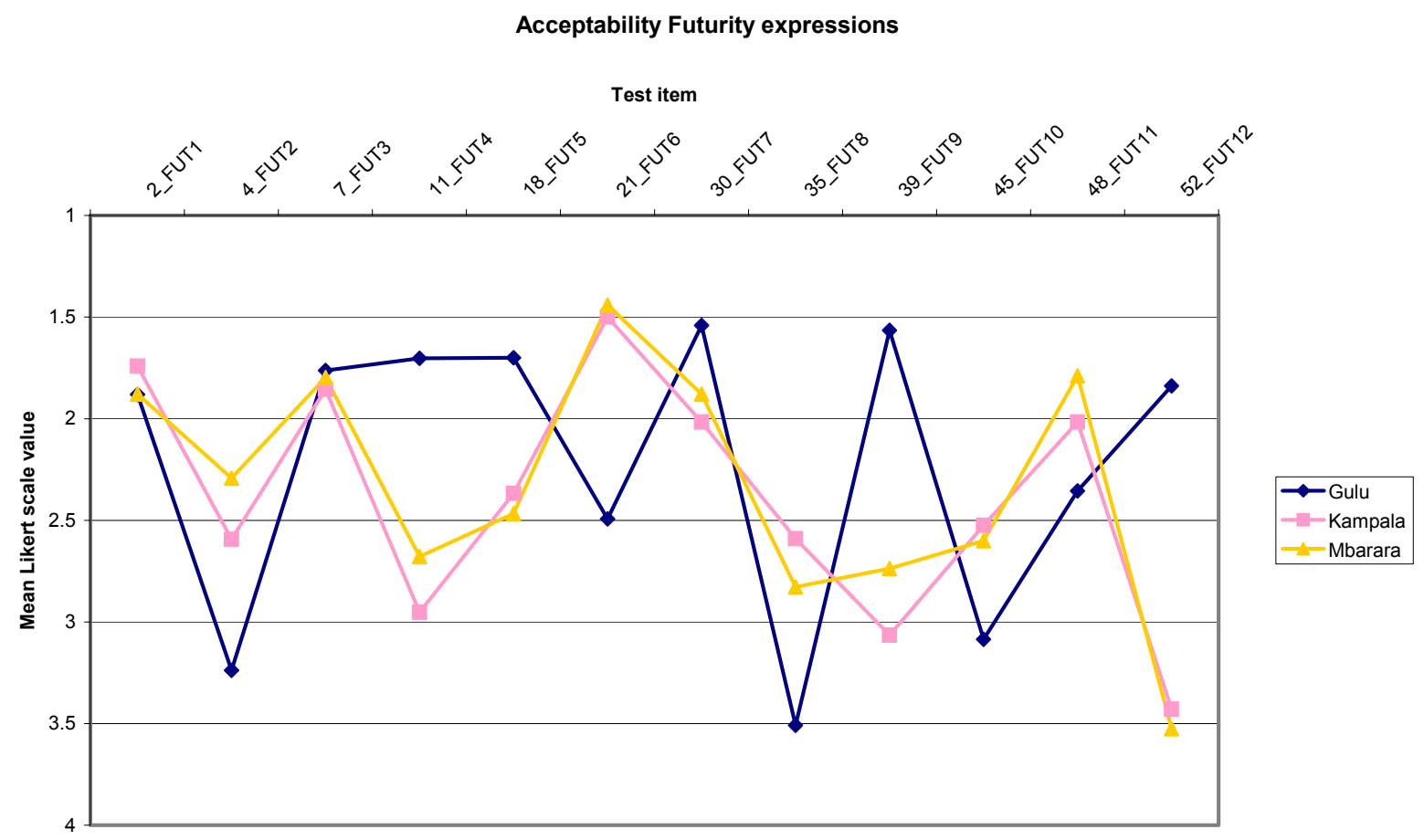

Figure 1. Acceptability ratings for expressions of futurity

Crucially, there are items, where the Gulu informants had ratings that were almost opposite to those of the respondents from Kampala and Mbarara. These are test items 11_FUT 4, 18 FUT 5, 21_FUT6, 39 FUT9, and 52_FUT12, i.e., coming to, will + progressive, would, shall and the going to-future. Forms with coming to, will + progressive, shall, and going to were rated fully acceptable by the Gulu respondents but less acceptable by the others. On the other hand, the sentence containing would was rated considerably less acceptable by Gulu respondents than by the others. Items that received, on average, the best ratings were 2_FUT1, i.e., the use of can to express futurity, and 7_FUT3, BE to. It seems that speakers with a Nilotic L1, i.e., the respondents from Gulu, assess the individual structures considerably different from speakers who have a Bantu L1. Interestingly, the going to-future, which is increasingly replacing the will-future in $\mathrm{AmE}$ and $\mathrm{BrE}$, does not seem to be a popular choice among the Bantu speakers.

\subsection{Assessment of Expressions of Modality}

Whilst English uses various modal verbs to express modality (in this study, obligation and ability), modality is mainly expressed by grammaticalised verbs that have developed, at different degrees, into modality markers in Luganda, Runyankore and Acholi (cf. e.g., Devos \& van Olmen, 2013). For example, in order to encode ability, Luganda uses the infix-like verbal derivative -sobola- (originally meaning 'manage', followed by a main verb in its infinitive form). Similarly, Runyankore uses -baasa- (also followed by a main verb in its infinitive form). But unlike what is the case with Luganda sobola, its lexical meaning ('manage') is still prevalently attested. The fact that a verb serves as both a lexical verb and a modality marker may have an impact on the variety of English spoken by L1 speakers of the language where the phenomenon is attested, e.g., Runyankore. Additionally, modality is also expressed through suffixes indicating subjunctive mood in a system of simple, complex and compound tenses. In Acholi, e.g., obligation is expressed by the use of the grammaticalised but free-standing verb myero, whose lexical meaning, 'to be fitting', has been lost. Whilst the Acholi modality gram for obligation myero requires the verb following it to be in the subjunctive mood, Taylor $(1985$, p. 164) states that "no special mood is used for obligation" in Runyankore. These differences may result in further variability as regards how 
speakers of these languages express modality in English as an L2. As regards L2 Englishes in general, Mesthrie (2004) explains that there seem to be different uses of modal auxiliaries, with the African L2 varieties substituting will for 'would', can for 'could', shall for 'should', and can or may for 'might' (the latter in Nigerian English only) but IndE using would for 'will' and could for 'can'. Modal verb usage has also been found to differ between BrE and AmE, with e.g. shall and subjunctive should considered archaic in AmE.

\subsubsection{Modals of Obligation}

Ten test items were used to investigate the acceptability of various modals of obligation as below. Whilst the majority contain forms that are used in BrE and AmE (must, should, have [got] to, need to), 51_OBLIG10 has a use of may that, according to Trudgill and Hannah (2017, p. 131), is used to express obligation in IndE.

3_OBLIG1: She must call the doctor.

5_OBLIG2: He should know the terms of his employment contract.

10_OBLIG3: The training must start from the university.

17_OBLIG4: Students have got to clean the blackboard.

27_OBLIG5: The Chinese teachers at Makerere shall also teach Chinese culture.

34_OBLIG6: They don't need to write the exam. (AmE)

37_OBLIG7: He needn't come early. (BrE)

41_OBLIG8: I need to write reports on the students' behaviour.

47_OBLIG9: You shall pay your tuition fees before the exams start.

51_OBLIG10: These mistakes may please be corrected. (IndE)

Similar to what is the case with expressions of futurity, responses to the test items containing the various modals of obligation also differ between the Gulu respondents and those from Kampala and Mbarara, as Figure 2 shows.

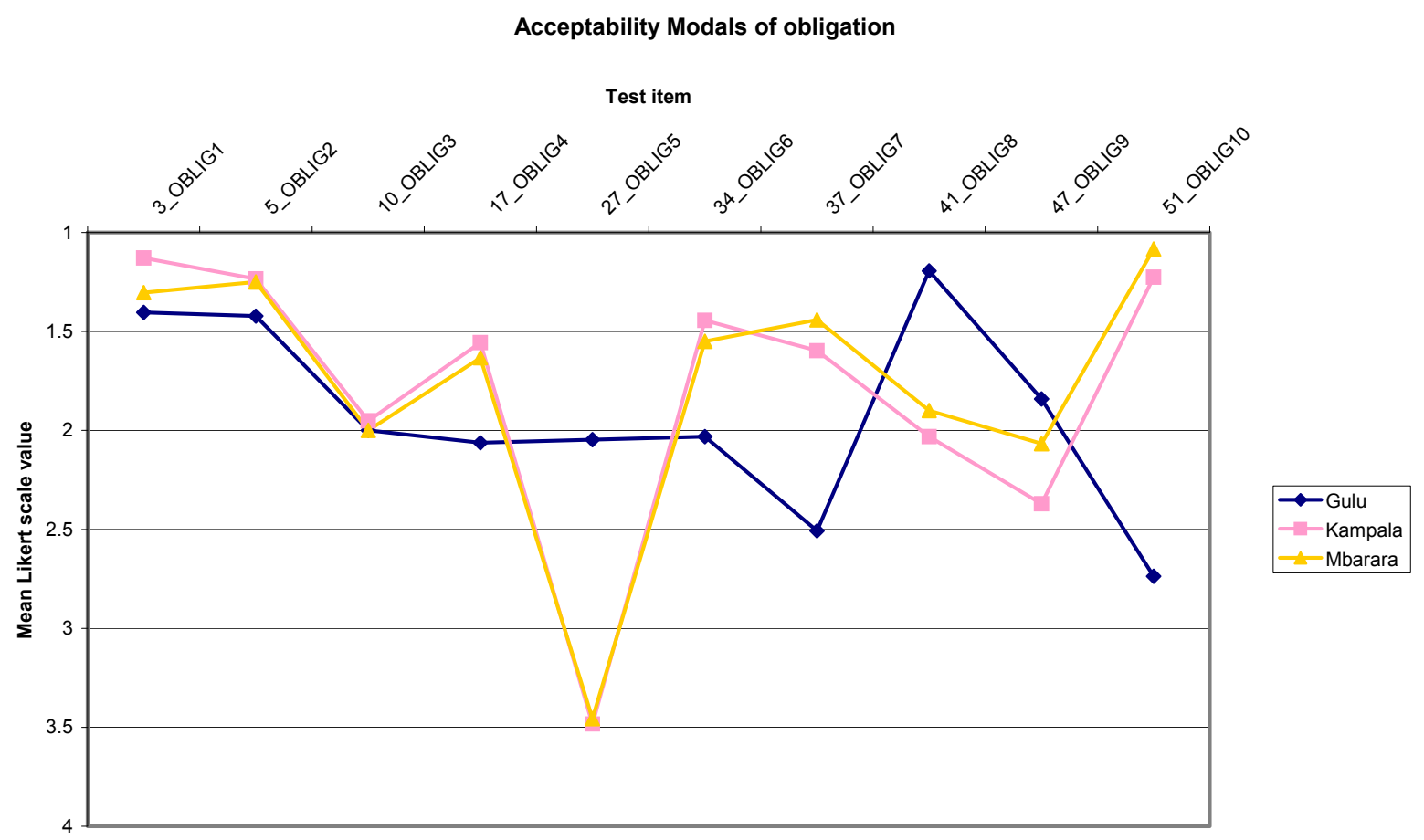

Figure 2. Acceptability ratings for modals of obligation

In the case of the modals of obligation, the main differences are found with 27_OBLIG6, 37_OBLIG7, 41_OBLIG8 and 51_OBLIG10, i.e., with shall, two test items that contain need to in an affirmative and in a negated sentence, and the item containing may. Interestingly, shall has traditionally been a modal verb associated 
with politeness in BrE. Despite this fact, it receives very negative ratings, between "somewhat unacceptable" and "completely unacceptable" from respondents in Kampala and Mbarara, which are predominantly Bantu speakers. Overall, all respondents ranked items 3_OBLIG1 and 5_OBLIG2 to be the most acceptable, showing a preference for the modals must and should. Potentially, the fact that the L1s use only one structure to express obligation triggers the focus on just two English surface forms.

\subsubsection{Modals of Ability}

For the inquiry into Ugandan's acceptance of various modals of ability, six test items, as shown below, were used. Whilst 23_ABIL2, 26_ABIL3 (may and BE able to) are encountered in the Standard English varieties BrE and AmE, the other test items have their origins in IndE, NigE and Black South African English (BSAfE).

8_ABIL1: After the referee might have arrived the match will begin. (NigE)

23_ABIL2: Vocabulary may be learned well by careful studies.

26_ABIL3: People are often not able to see a doctor without delay.

28_ABIL4: I could do well in my exams this afternoon. (IndE)

42_ABIL5: Let's finish now so that we could be there early. (IndE)

50_ABIL6: You are from Arua, so you can be able to speak Lugbara. (BSAfE)

In some contrast to the findings reported so far, the judgements for modals of ability are somewhat similar across all three locations and, thus, across speakers with Bantu and Nilotic L1s. It is only test item 26_ABIL3, to be able to in a negated sentence, for which assessments differ, with respondents from Gulu rating it more acceptable than the others, for whom the sentence is between the "somewhat unacceptable" and "completely unacceptable" end of the Likert-scale.

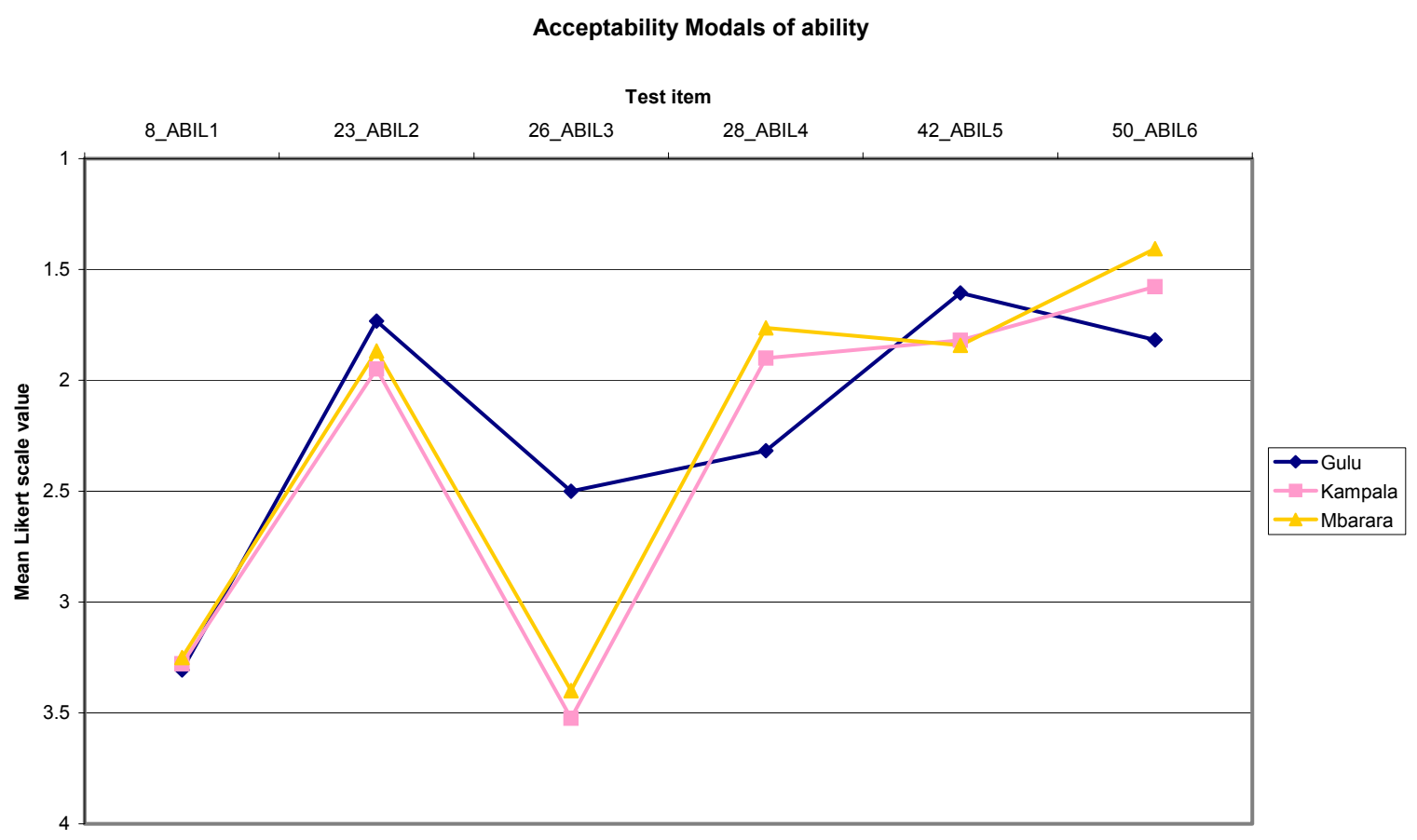

Figure 3. Acceptability ratings for modals of ability

Overall, 50_ABIL6 was rated most acceptable, closely followed by 42_ABIL5, one of the two being a form frequently reported for various African Englishes, can be able to, and the other could, having often been attested in IndE as a polite alternative to can. Interestingly, the Standard English BE able to was ranked negatively by the Kampala and Mbarara respondents and 8_ABIL1, the NigE form, worst altogether. 


\subsection{Assessments of Uses of Prepositions}

Expressions of spatial and temporal relations are complex in the Bantu languages. Ashton et al. (1954, p. 414) state that "[b]eyond the - A of Relationship (sic!), it is doubtful if Luganda has any true prepositions." In fact, prepositional content may be expressed by the verb itself, by adverbial particles, by locatives with nominal properties, by applied verbs or by the prefix $n a$ to mark a noun as an instrument (expressing with or by). Similarly, in Runyankore, adverbs function as prepositions, yielding five simple prepositions and a number of compound ones (Taylor, 1985, p. 181). Acholi, on the other hand, possesses a complex system of prepositions, albeit with meanings not fully overlapping with the English expressions. Despite this complexity, Mesthrie (2004, p. 1140) finds that "[p]repositions are underdifferentiated in all the (L1 and L2) varieties reported on." There are also individual differences between $\mathrm{BrE}$ and $\mathrm{AmE}$, e.g. using at the weekend(s) and on the weekend(s), respectively. Relatedly, "[p]hrasal and prepositional verbs are subject to immense variation in L2 Englishes" (Mesthrie, 2004, p. 1135). In fact, UgE has also been shown to have developed a number of what Nelson and Hongtao (2012) call "innovative particle verbs", with into being particularly frequent in their formation.

Our test items probed into both spatial as well as temporal prepositions.

\subsubsection{Spatial Prepositions}

The following six test items were employed to probe into the acceptability of spatial preposition uses. 14_SPAT1, contains a characteristic use of from in UgE. 19_SPAT2 contains a use of in instead of into, in 24_SPAT3, in is used instead of along, and 46_SPAT contains a zero preposition.

14_SPAT1: He decided to eat from the restaurant. (UgE)

19_SPAT2: Many tourists come in the country. (KenE)

24_SPAT3: He lives somewhere in the coast. (KenE)

36_SPAT4: He sells clothes at the market. (UgE)

43_SPAT5: He wears closed shoes in school.

46_SPAT6: Actually, this place I have not been. (IndE)

Similar to what is the case with the modals, the spatial prepositions are ranked similar by the Gulu, the Kampala and the Mbarara informants, with the exception of 46_SPAT6, i.e., the sentence containing the zero preposition. This was ranked considerably less acceptable by the Gulu respondents than by the others, for whom the sentence was fairly acceptable.

\section{Acceptability Spatial prepositions}

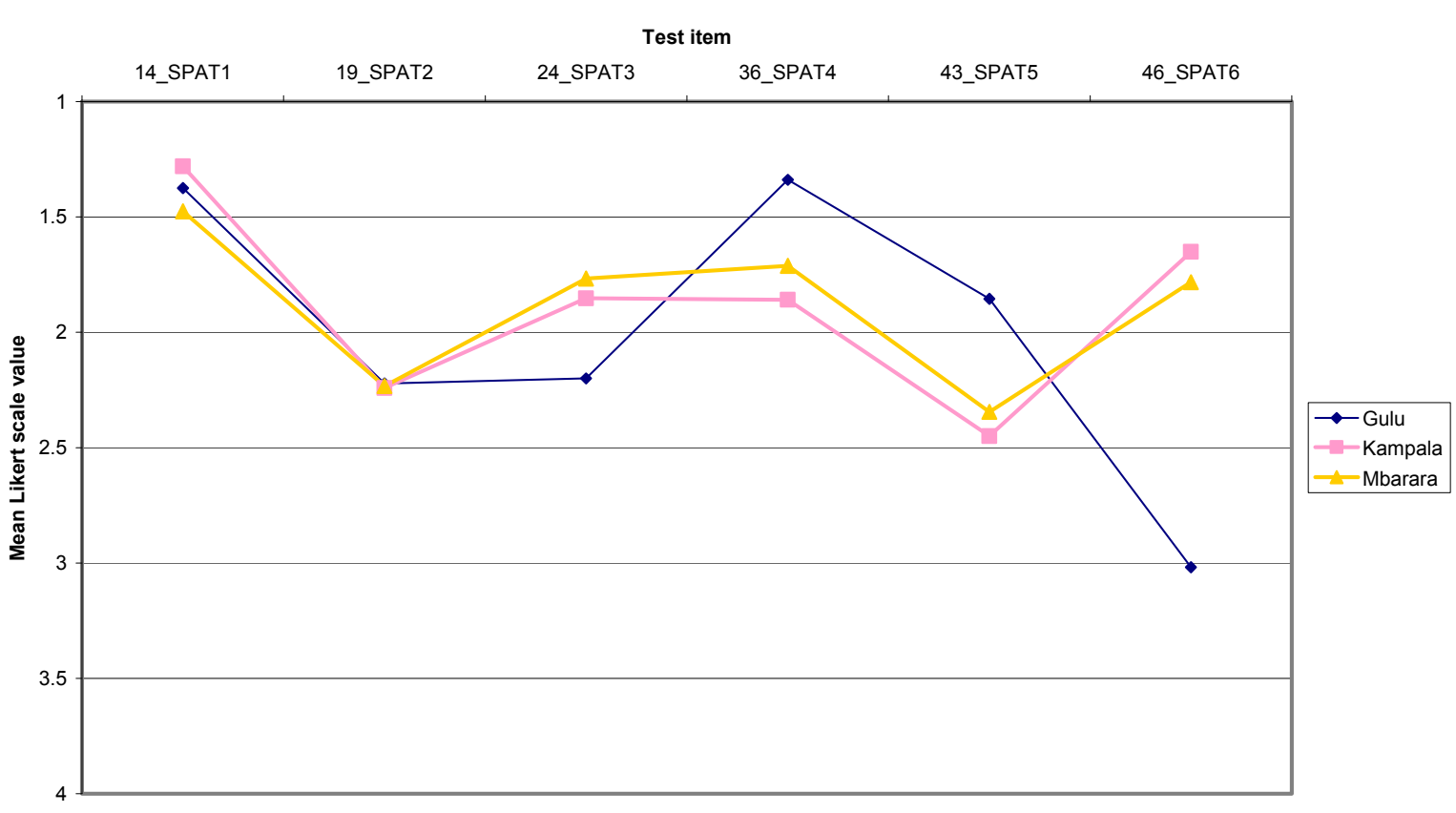

Figure 4. Acceptability ratings for spatial prepositions 
Overall, 14_SPAT1, i.e., the use of the UgE use of from instead of at was ranked best, close to "completely acceptable" by our informants, pointing to an acceptability of an endogenous form here. Again, the ratings for the various test items differ noticeably between the informants in Gulu (with Nilotic L1s) and those in Kampala and Mbarara (with mainly Bantu L1s). This is most pronounced as regards the assessment of the zero preposition.

\subsubsection{Temporal Prepositions}

For the study of Ugandans' acceptability of uses of temporal prepositions, four test items were used as below:

12_TEMP1: The musicians performed on the weekend.

16_TEMP2: He went to visit his parents at the weekend.

22_TEMP3: I am going on vacation during the next term break.

40_TEMP4: The musician's new video became popular over the holiday.

12_TEMP1 and 16_TEMP2 contain the two standard prepositions, with the former being the American and the latter the British preference. Interestingly, as Figure 5 documents, the American form on the weekend was ranked more acceptable than the British at the weekend, despite the fact that $\mathrm{BrE}$ continues to be the model taught in schools This seems to confirm Mair's (2013) assumption that AmE, via the media, exerts more influence on varieties than $\mathrm{BrE}$ does.

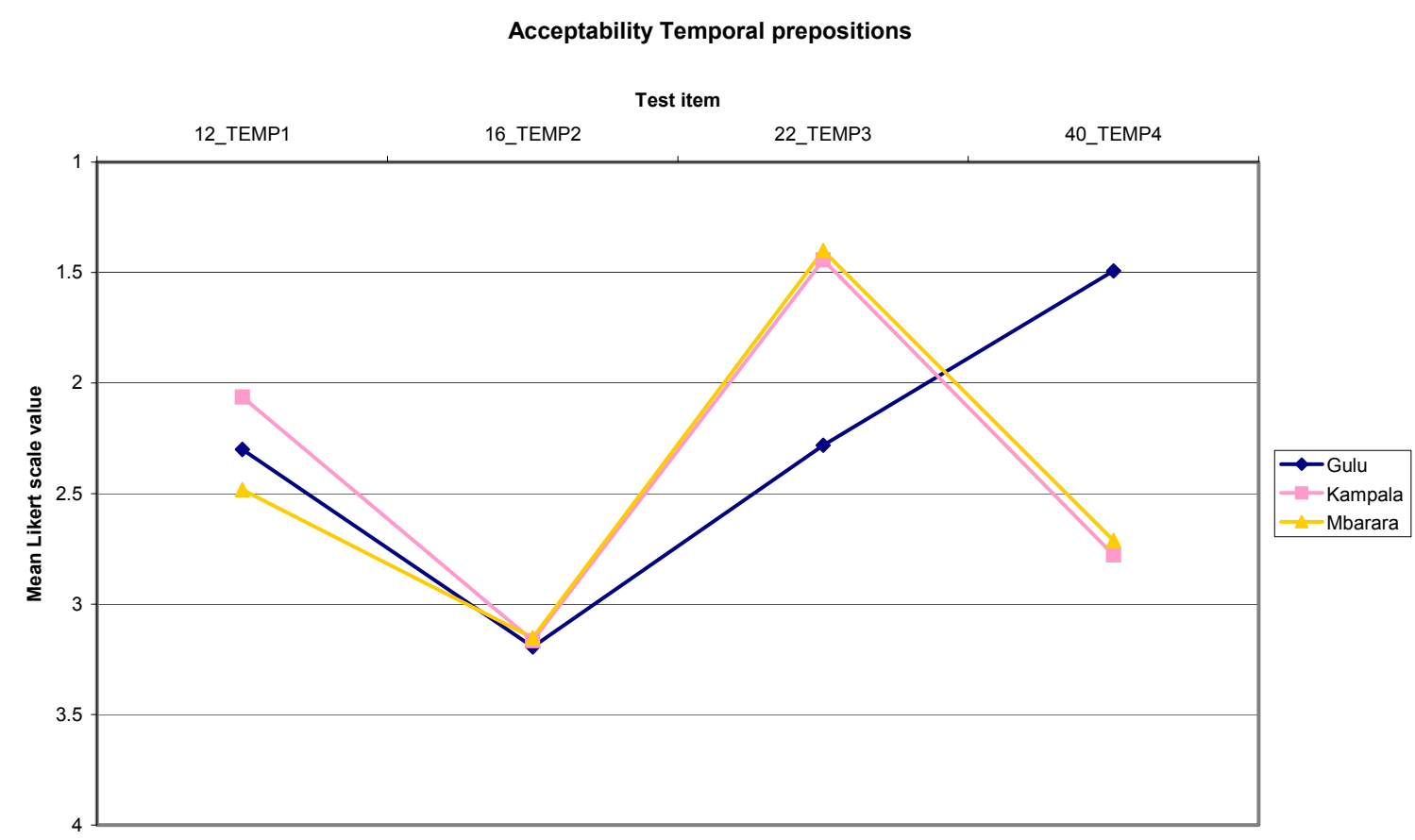

Figure 5. Acceptability ratings for temporal prepositions

As regards during and over in test items 22_TEMP3 and 40_TEMP4, we again find considerable differences across the Gulu versus Kampala and Mbarara divide, with speakers in Gulu ranking during less acceptable than over, whilst the opposite is the case with respondents from Kampala and Mbarara.

\section{Conclusion}

This paper has reported on the results of acceptability test that collected the assessments of various expressions of futurity, obligation, ability and of uses of spatial and temporal prepositions from various varieties of English in three locations in Uganda. The results reveal how acceptable or inacceptable structures from various varieties of English are held to be by Ugandans. Interestingly, although not unexpectedly, it was at times a structure used in a second language variety that received good ratings towards "completely acceptable". This is the case with 
can to express futurity, can be able to and could in the case of modals of ability and the spatial preposition from where $\mathrm{BrE}$ and $\mathrm{AmE}$ would use at.

Crucially, the acceptability ratings made in those locations where respondents are speakers of Bantu languages often differ considerably from those obtained in Gulu, where respondents are speakers of Nilotic languages (Note 8). Respondents from the two locations where a Bantu language is spoken by the majority of the population, and also by our informants, cluster together, even if these show micro-variation as regards the different structures investigated here. This is the case with many of the expressions of futurity, shall to express obligation, $B E$ able to to express ability, the deletion of a spatial preposition and the use of the temporal preposition over.

The various results also indicate that some of the predictions made by recent models of world Englishes do not seem to be reflected in Ugandans' assessments of the various test items. For example, the rather negative rating of the going to-future is in contrast to the influence of AmE assumed in Mair's (2013) model. On the other hand, the findings for the temporal prepositions on and at document a clear preference for the AmE on the weekend. Also, the ratings for items that have their origins in NigE or IndE point towards a rather low influence of these two varieties on Ugandan's preferences for English expressions and structures. At the same time, other findings, i.e., the positive rating of the preposition from, may reflect endonormative stabilisation in the sense of Schneider (2007), at least as regards individual grammatical areas.

However, whether individual structures are deemed acceptable or not does not necessarily mean that speakers will employ these themselves or not. Rather, familiarity with the features following regular exposure to them, e.g. through interaction with speakers of those varieties for which they are typical or through their encounter in films or on the Internet may be a factor triggering positive evaluations. Studies have shown that acceptability judgements are sensitive to various sociolinguistic and social variables of which one is the respondents' proficiency level in English. Lee and Collins (2006), in a study on linguistic acceptability of Hong Kong English, found that acceptability judgements of secondary school students with high English proficiency showed a stronger preference for options that adhere to prescriptive norms. The authors explain this by a potentially higher orientation towards prescriptive attitudes as encountered in grammar books, which high proficiency students may consult more often (Lee \& Collins, 2006).

As Phillips (2009) emphasises, any acceptability judgements need to be understood in relation to factual linguistic behaviours. Future analyses of the language productions captured in our interviews need to show how the acceptability ratings correspond to real behaviour.

\section{Reference}

Ashton, E. O. et al. (1954). A Luganda Grammar. London: Longmans, Green and Co.

Bayiga, F. (2016). Profiles of multilingualism in Kampala: An analysis of language biographies and linguistic repertoires among university students. PhD dissertation. Stellenbosch University, South Africa. Retrieved from http://hdl.handle.net/10019.1/98800

Biber, D. et al. (1999). Longman Grammar of Spoken and Written English. London: Longman.

Biewer, C. (2011). Modal auxiliaries in second language varieties of English. A learner's perspective. In J. Mukherjee \& M. Hundt (Eds.), Exploring Second-Language Varieties of English and Learner Englishes: Bridging a Paradigm Gap (pp. 7-33). Amsterdam: Benjamins. https://doi.org/10.1075/scl.44.02bie

Blommaert, J. (2010). The Sociolinguistics of Globalisation. Cambridge: Cambridge University Press. https://doi.org/10.1017/CBO9780511845307

Devos, M., \& van Olmen, D. (2013). Describing and explaining the variation of Bantu imperatives and prohibitives. Studies in Language, 37(1), 1-57. https://doi.org/10.1075/s1.37.1.01dev

Filppula, M., Klemola, J., \& Sharma, D. (eds.) (2017). Oxford Handbook of World Englishes. Oxford: Oxford University Press.

Fisher, A. E. C. (2000). Assessing the state of Ugandan English. English Today, 16(1), 57-61. https://doi.org/10.1017/S0266078400011470

Gilquin, G. (2015). At the interface of contact linguistics and second language acquisition research: New Englishes and Learner Englishes compared. English World-Wide, 36(1), 91-124. https://doi.org/10.1075/eww.36.1.05gil

Huber, M. (2013). Regional profile: Africa. In B. Kortmann \& K. Lunkenheimer (Eds.), The Mouton World Atlas 
of Variation in English (pp. 806-823). Berlin: Mouton de Gruyter.

Hundt, M. (2013). The diversification of English: Old, new and emerging epicenters. In D. Schreier \& M. Hundt (Eds.), English as a Contact Language (pp. 182-203). Cambridge. Cambridge University Press. https://doi.org/10.1017/CBO9780511740060.011

Isingoma, B. (2013). Innovative pragmatic codes in Ugandan English: A relevance-theoretic account. Argumentum, 9, 19-31.

Isingoma, B. (2014a). Lexical and grammatical features of Ugandan English. English Today, 30(2), 51-56. https://doi.org/10.1017/S0266078414000133

Isingoma, B. (2014b). Empaako "praise names": an historical, sociolinguistic, and pragmatic analysis. African Study Monographs, 35(2), 85-98. https://doi.org/10.14989/189520

Isingoma, B. (2016a). Languages in East Africa: policies, practices and perspectives. Sociolinguistic Studies, 10(3), 433-454. https://doi.org/10.1558/sols.v10i3.27401

Isingoma, B. (2016b). Lexical borrowings and calques in Ugandan English. In C. Meierkord, B. Isingoma \& S. Namyalo (Eds.), Ugandan English: Its Sociolinguistics, Structure and Uses in a Globalising Post-protectorate (pp. 149-172). Amsterdam: Benjamins. https://doi.org/10.1075/veaw.g59.07isi

Isingoma, B., \& Meierkord, C. (2016). Ugandan English - challenges to, and input for, current theories. In C. Meierkord, B. Isingoma \& S. Namyalo (Eds.), Ugandan English: Its Sociolinguistics, Structure and Uses in a Globalising Post-protectorate (pp. 1-15). Amsterdam: Benjamins. https://doi.org/10.1075/veaw.g59.01isi

Isingoma, B., \& Meierkord, C. (2019). Capturing the lexicon of Ugandan English: ICE-Uganda, its limitations and effective complements. In U. A. Esimaje, U. Gut \& E. B. Antia (Eds.), Corpus Linguistics and African Englishes (pp. 293-328). Amsterdam: John Benjamins. https://doi.org/10.1075/scl.88.13isi

Kachru, B. (1985). Standards, codification and sociolinguistic realism: the English language in the outer circle. In R. Quirk \& H. G. Widdowson (Eds.), English in the World: Teaching and Learning the Language and Literatures (pp. 11-30). Cambridge: Cambridge University Press.

Kirkpatrick, A. (2007). World Englishes. Implications for International Communication and English Language Teaching. Cambridge: Cambridge University Press.

Kitching, A. L. (1932). An Outline Grammar of the Acholi Language. London: Sheldon Press.

Kortmann, B., \& Schneider, E. (eds.) (2004). A Handbook of Varieties of English (Vol. 1: Phonology \& Vol. 2: Morphology and Syntax). Berlin: De Gruyter Mouton. https://doi.org/10.1515/9783110197181

Kortmann, B., \& Lunkenheimer, K. (eds.) (2013). The Mouton World Atlas of Variation in English. Berlin: De Gruyter. https://doi.org/10.1515/9783110280128

Ladefoged, P., Glick, R., \& Criper, C. (1972). Language in Uganda. Oxford: Oxford University Press.

Lee, J. F. K., \& Collins, P. (2006). Linguistic Acceptability in Hong Kong English. Asian Englishes, 9(1), 24-40. https://doi.org/10.1080/13488678.2006.10801175

Mair, C. (2013). The World System of Englishes. Accounting for the transnational importance of mobile and mediated vernaculars. English World-Wide, 34(3), 253-278. https://doi.org/10.1075/eww.34.3.01mai

McArthur, T. (2002). Oxford Guide to World English. Oxford: Oxford University Press.

Meierkord, C. (2012). Interactions across Englishes. Linguistic Choices in Local and International Contact Situations. Cambridge: Cambridge University Press. https://doi.org/10.1017/CBO9781139026703

Meierkord, C. (2016a). A social history of English(es) in Uganda. In C. Meierkord, B. Isingoma \& S. Namyalo (Eds.), Ugandan English: Its Sociolinguistics, Structure and Uses in a Globalising Post-protectorate (pp. 51-71). Amsterdam: Benjamins. https://doi.org/10.1075/veaw.g59.03mei

Meierkord, C. (2016b). Diphthongs in Ugandan Englishes: Evidence for and against variety status and Interactions across Englishes. In C. Meierkord, B. Isingoma \& S. Namyalo (Eds.), Ugandan English: Its Sociolinguistics, Structure and Uses in a Globalising Post-protectorate (pp. 121-147). Amsterdam: Benjamins. https://doi.org/10.1075/veaw.g59.06mei

Meierkord, C. (2016c). Speech acts in Ugandan English social letters: Investigating the influence of socio-cultural context. In C. Meierkord, B. Isingoma \& S. Namyalo (Eds.), Ugandan English: Its Sociolinguistics, Structure and Uses in a Globalising Post-protectorate (pp. 227-248). Amsterdam: 
Benjamins. https://doi.org/10.1075/veaw.g59.10mei

Meierkord, C., Isingoma, B., \& Namyalo, S. (eds.) (2016). Ugandan English: Its Structure, Use and in a Globalising Post-Protectorate. Amsterdam: Benjamins. https://doi.org/10.1075/veaw.g59

Meierkord, C. (in preparation). Interactions across Englishes and their effects in Uganda. Evidence from expressions of futurity.

Mesthrie, R. (2004). Synopsis: morphological and syntactic variation in Africa and south and southeast Asia'. In: B. Kortmann, K. Burridge, R. Mesthrie, Schneider \& C. Upton (Eds.), A Handbook of Varieties of English (Vol 2: Morphology and Syntax, pp. 1132-1141). Berlin: Mouton de Gruyter. https://doi.org/10.1515/9783110175325.2.1132

Mesthrie, R., \& Bhatt, R. M. (2008). World Englishes: The Study of New Linguistic Varieties. Cambridge: Cambridge University Press. https://doi.org/10.1017/CBO9780511791321

Meyerhoff, M., \& Niedzielski, N. (2003). The globalisation of vernacular variation. Journal of Sociolinguistics, 7(4), 534-555. https://doi.org/10.1111/j.1467-9841.2003.00241.x

Michieka, M. (2009). Expanding circles within the outher circle: The rural Kisii in Kenya. World Englishes, 28(3), 352-364. https://doi.org/10.1111/j.1467-971X.2009.01597.x

Mufwene, S. (2001). The Ecology of Language Evolution. Cambridge: Cambridge University Press. https://doi.org/10.1017/CBO9780511612862

Mugumya, L. (2013). The Discourse of Conflict: An Appraisal Analysis of Newspaper Genres in English and Runyankore-Rukiga in Uganda (2001-2010). Unpublished PhD Thesis. Stellenbosch, South Africa: Stellenbosch University. Retrieved from http://hdl.handle.net/10019.1/79929

Mukherjee, J., \& Hundt, M. (eds.) (2011). Exploring Second-Language Varieties of English and Learner Englishes. Amsterdam: Benjamins. https://doi.org/10.1075/scl.44

Nakayiza, J. (2013). The Sociolinguistics of Multilingualism in Uganda: A Case Study of the Official and Non-Official Language Policy, Planning and Management of Luruuri-Lunyara and Luganda. Unpublished $\mathrm{PhD}$ thesis. London, UK: University of London, School of Oriental and African Studies. Retrieved from eprints.soas.ac.uk/15950/1/Nakayiza_3469.pdf

Namyalo, S., Isingoma, B., \& Meierkord, C. (2016). Towards assessing the space of English in Uganda's linguistic ecology: facts and issues. In C. Meierkord, B. Isingoma \& S. Namyalo (Eds.), Ugandan English: Its Sociolinguistics, Structure and Uses in a Globalising Post-protectorate (pp. 19-49). Amsterdam: Benjamins. https://doi.org/10.1075/veaw.g59.02nam

Namyalo, S., \& Nakayiza, J. (2014). Dilemmas in implementing language rights in multilingual Uganda. Current Issues in Language Planning, 16(4). 409-424. https://doi.org/10.1080/14664208.2014.987425

Nassenstein, N. (2016). A preliminary description of Ugandan English. World Englishes, 35(3), 396-420. https://doi.org/10.1111/weng.12205

Nelson, G., \& Hongtao, R. (2012). Particle Verbs in African Englishes: Nativization and Innovation. In M. Hundt \& U. Gut (Eds.), Mapping Unity and Diversity Worldwide: Corpus-based Studies of New Englishes (pp. 197-213). Amsterdam: Benjamins. https://doi.org/10.1075/veaw.g43.08nel

Phillips, C. (2009). Should we impeach armchair linguists? Japanese/Korean Linguistics, 17, 49-64.

Quirk, R., Greenbaum, S., Leech, G., \& Svartvik, J. (1985). A Comprehensive Grammar of the English Language. London: Longman.

Rathore-Nigsch, C., \& Schreier, D. (2016). Indian English in Uganda: The historical sociolinguistics of a migrant community. In C. Meierkord, S. Namyalo \& I. Bebwa (Eds.), Ugandan English: Its Sociolinguistics, Structure and Uses in a Globalising Post-Protectorate (pp. 251-274). Amsterdam: Benjamins. https://doi.org/10.1075/veaw.g59.11rat

Rosendal, T. (2010). Linguistic Landshapes. A Comparison of official and non-official language management in Rwanda and Uganda, focussing on the position of African languages. Unpublished $\mathrm{PhD}$ thesis, University of Gothenburg, Sweden. Retrieved from https://gupea.ub.gu.se/bitstream/2077/22227/1/gupea_2077_22227_1.pdf)

Schmied, J. (1991). English in Africa. An Introduction. London: Longman.

Schmied, J. (2004a). East African English (Kenya, Uganda, Tanzania): phonology. In E. Schneider et al. (Eds.), 
A Handbook of Varieties of English (Vol. 1 Phonology, pp. 918-930). Berlin: De Gruyter. https://doi.org/10.1515/9783110175325.1.918

Schmied, J. (2004b). East African English (Kenya, Uganda, Tanzania): morphology and syntax. In B. Kortmann et al. (Eds.), A Handbook of Varieties of English (Vol, 2; Morphology and Syntax, pp. 929-947). Berlin: De Gruyter. https://doi.org/10.1515/9783110175325.2.929

Schmied, J. (2006). East African Englishes. In B. Kachru, Y. Kachru \& C. Nelson (Eds.), The Handbook of World Englishes (pp. 188-202). Oxford: Blackwell. https://doi.org/10.1002/9780470757598.ch12

Schmied, J. (2017). East African English. In M. Filppula, J. Klemola \& D. Sharma (Eds.), The Oxford Handbook of World Englishes (pp. 472-489). Oxford: Oxford University Press. https://doi.org/10.1093/oxfordhb/9780199777716.013.35

Schneider, E. (2007). Postcolonial English. Varieties of English Around the World. Cambridge: Cambridge University Press. https://doi.org/10.1017/CBO9780511618901

Schneider, E. (2011). English Around the World: An Introduction. Cambridge: Cambridge University Press. https://doi.org/10.1017/CBO9780511781711

Ssempuuma, J. (2013). Ugandan English. In B. Kortmann \& K. Lunkenheimer (Eds.), The Mouton World Atlas of Variation in English (pp. 475-482). Berlin: De Gruyter Mouton. https://doi.org/10.1515/9783110280128.475

Ssempuuma, J. (2019). Morphological and Syntactic Feature Analysis of Ugandan English. Frankfurt a.M.: Lang. https://doi.org/10.3726/b15305

Ssempuuma, J., Isingoma, B., \& Meierkord, C. (2016). The use of the progressive in Ugandan English. In C. Meierkord, B. Isingoma, \& S. Namyalo (Eds.), Ugandan English: Its Sociolinguistics, Structure and Uses in a Globalising Post-protectorate (pp. 173-199). Amsterdam: Benjamins. https://doi.org/10.1075/veaw.g59.08sse

Ssentanda, M. E. (2014a). Mother Tongue Education and Transition to English Medium Education in Uganda: Teachers' Perspectives and Practices versus Language Policy and Curriculum. Unpublished PhD Thesis. Stellenbosch, South Africa: University of Stellenbosch. Retrieved from http://hdl.handle.net/10019.1/95855

Ssentanda, M. E. (2014b). The challenges of teaching reading in Uganda: Curriculum guidelines and language policy viewed from the classroom. Apples - Journal of Applied Language Studies, 8(2), 1-22. Retrieved from http://www.apples.jyu.fi/ArticleFile/download/439

Ssentanda, M. E., Huddleson, K., \& Southwood, F. (2016). The politics of mother tongue education: the case of Uganda. Per Linguam, 32(3), 60-78. https://doi.org/10.5785/32-3-689

Szmrecsanyi, B. et al. (2016). Around the wolrd in three alternations. Modeling syntactic variation in varieties of English. English World-Wide, 37(2), 109-137. https://doi.org/10.1075/eww.37.2.01szm

Taylor, Ch. (1985). Nkore-Kiga. London: Croom Helm.

Trudgill, P., \& Hannah, J. (2017). International English. London: Routledge. https://doi.org/10.4324/9781315192932

Tukwasibwe, C. (2014). The influence of indigenous languages on Ugandan English as used in the media. $\mathrm{PhD}$ dissertation. Rhodes University, South Africa. Retrieved from http://contentpro.seals.ac.za/iii/cpro/DigitalItemViewPage.external?sp=1015637

Wolf, H.-G. (2010). East and West African Englishes: differences and commonalities. In A. Kirkpatrick (Ed.), The Routledge Handbook of World Englishes (pp. 197-211). London: Routledge.

\section{Notes}

Note 1 . This is different only with regard to the former US-American protectorate of The Philippines, for which a considerable body of publications as well as a component of the International Corpus of English exist.

Note 2. However, Kachru (1985, p. 17) mentions potential overlaps between the different circles in passing.

Note 3. Mair (2013, p. 258) categorises IndE and NigE as "super-central" varieties and KenE as "central varieties", assuming that higher ranking varieties will make a transnational impact, e.g. in terms of borrowing (2013, p. 261) on the lower-ranking "peripheral varieties" in the system, such as UgE. 
Note 4. Contact with IndE is, potentially, also possible through interaction with Uganda's Asian population. In the past, before the earlier Asian population was expelled from the country by Amin, however, such contact hardly existed, and if it did, it did not take place in English (cf. Rathore \& Schreier, 2016), and judging from informal comments, contact today also is very restricted.

Note 5. Probably, these processes will mostly not be conscious, particularly when speakers of English need to be considered as learners and are unaware of the influence their L1 exerts and of the particular features, phonological, grammatical, lexical and pragmatic, that characterise their English.

Note 6. This research has been funded by the German Research Council (DFG) under grant no. ME 1775/10-1.

Note 7. But see Meierkord (in preparation).

Note 8. This is true for the vast majority of our respondents. However, both the Kampala and Mabarara data contain Nilotic speakers and the Gulu data individual speakers of Bantu languages.

\section{Copyrights}

Copyright for this article is retained by the author, with first publication rights granted to the journal.

This is an open-access article distributed under the terms and conditions of the Creative Commons Attribution license (http://creativecommons.org/licenses/by/4.0/). 